\title{
A comparative analysis of gas and liquid phase standard spiked solid sorbent tubes for the determination of volatile organic compounds in indoor air by TD-GC/MS
}

\author{
Hyun-Woo Lim, Sung-Won Jung, Chul-Ho Kang, Jin-Sook Park ${ }^{\mathbf{1}}$, \\ Byeong Moo Park ${ }^{2}$ and Yong-Wook Choi ${ }^{1,3, \star}$ \\ ${ }^{1}$ Department of Environmental Science, Jeonju University, 303 Chunjam-Ro, Wansan-Gu, Jeonju 560-759, Korea \\ ${ }^{2}$ Namwon Jeil High School, 1206 Nosong-Ro, Namwon, 590-090, Korea \\ ${ }^{3}$ Specialized Institute of Environmental Health Science, Jeonju University, Jeonju 560-759, Korea \\ (Received Januay 6, 2013; Revised August 3, 2013; Accepted August 3, 2013)
}

\section{열탈착/저온농축-GC/MS에 의한 실내공기 중 휘발성 유기화합물 정량용 기체상 및 액체상 표준물질 첨가한 고체 흡착관의 비교 분석}

\author{
임현우 · 정성운 · 강철호 · 박진숙 ${ }^{1} \cdot$ 박병무 $^{2}$ - 최용욱 ${ }^{1,3, \star}$ \\ ${ }^{1}$ 전주대학교 환경과학과, ${ }^{2}$ 남원제일고등학교, ${ }^{3}$ 전주대학교 환경보건전문연구소 \\ (2013. 1. 6. 접수, 2013. 8. 3. 수정, 2013. 8. 3. 승인)
}

\begin{abstract}
The optimization of analytical method for the thermal desorption of seven VOCs (volatile organic compounds) by TD-GC/MS (thermal desorption-gas chromatograph-mass spectrometer) with solid phase sorbent tube, and comparative analysis for the determination of VOCs plotted by standard sorbent tubes prepared using both gas phase and liquid phase materials were investigated. The result of paired t-test showed that a liquid phase standard sorbent tube method was in agreement with a gas phase standard sorbent tube method for six species of VOCs including benzene, toluene, ethylbenzene, o-, m-, and p-xylene except for styrene at the significance level $(\alpha=0.01)$, while the $15.6 \%$ of difference in response factor between both of gas phase and liquid phase standard plotting for the determination of styrene showed that both methods were significantly different at the significance level. Therefore, the liquid phase standard plotting method was employed to reduce erroneous data for the determination of styrene including BTEX. Under the optimized analytical method by liquid phase standard sorbent tube, recovery was between $100 \pm 5 \%$ for 7 species of VOCs, reproducibility ranged from 0.3 to $7.7 \%$, and method detection limit (MDL) ranged from $0.01 \mu \mathrm{g} / \mathrm{m}^{3}$ for o-xylene to $0.27 \mu \mathrm{g} / \mathrm{m}^{3}$ for toluene. The optimized standard method was applied to determine VOCs VOCs from indoor air of of dormitory, one bedroom apartment, and a new car.
\end{abstract}

요 약: 본 연구는 고체 흡착관과 TD-GC/MS를 이용하여 7종의 휘발성 유기화합물에 대한 열탈착 분석

$\star$ Corresponding author

Phone : +82-(0)63-220-2555 Fax : +82-(0)63-220-2054

E-mail : cyw411@ij.ac.kr 
조건을 최적화하였고, 기체상 및 액상 표준물질 첨가한 고체 흡착관을 사용하여 얻어진 검정곡선으로부 터 휘발성 유기화합물을 비교 정량하였다. 대응표본 t-검정 결과, 스타일렌을 제외하고 벤젠, 톨루엔, 에 틸벤젠, o-, m- 및 p-자일렌을 포함한 6종의 휘발성 유기화합물에 대해서는 액상 표준물질에 의한 표준 흡착관법이 기체상에 의해 제작된 표준 흡착관법이 유의수준 $(\alpha=0.01)$ 에서 일치한 반면, 스타일렌에 대 해서는 기체상 및 액체상으로 작성된 검정곡선에서 감응인자가 $15.6 \%$ 차이가 발생하였는데 이것은 두 방법 간에 유의한 차이가 있다는 것을 의미하였다. 따라서 BTEX를 포함한 스타일렌을 정량하는데 오차 를 감소시키기 위해 액상 표준물질을 이용한 고체상 흡착관법을 사용하였다. 바로 그 점이 이 논문의 핵 심내용임. 즉, 고가의 표준가스 대신에 저가의 액상 표준물질을 사용하여 정량하더라도 스타일렌 이외에 거의 동일한 값을 나타내기 때문임. 액체상 표준물법 조건에서 7 종의 $\mathrm{VOCs}$ 의 회수율은 $100 \pm 5 \%$, 재현 성은 $0.3 \sim 7.7 \%$, 검출한계는 o-자일렌의 $0.01 \mu \mathrm{g} / \mathrm{m}^{3}$ 에서부터 톨루엔의 $0.27 \mu \mathrm{g} / \mathrm{m}^{3}$ 까지 범위를 나타내었다. 이러한 최적화된 분석방법을 신축 기숙사, 원룸 아파트 및 신차의 실내공기 중 휘발성 유기화합물을 정 량하는데 적용하였다.

Key words: indoor air, TVOCs s, thermal desorption, Tenax TA, solid sorbent tube

\section{1. 서 론}

최근 실내공기질 관리의 중요성이 인식되면서 실내 공기 중에 존재하는 오염물질에 대한 정확한 정성 및 정량분석을 통한 신뢰성 있는 실내공기질 평가가 요 구되고 있다. 실내공기오염물질 중 하나인 휘발성 유 기화합물(volatile organic compounds, VOCs)은 실내의 다양한 오염원으로부터 극미량이 기체상으로 방출되며 휘발성 유기화합물이 실내공기 중에 저농도 수준에서 지속적으로 노출될 경우 아토피 또는 새집증후군(sick house syndrome)과 같은 환경성 질환을 일으키는 것으 로 알려져 있다. ${ }^{1-4}$ 뿐만 아니라 실내공기 중에 존재하 는 오존 $\left(\mathrm{O}_{3}\right)$, 질소산화물 $\left(\mathrm{NO}_{\mathrm{x}}\right)$ 과 기체상 화학반응을 일 으켜 인체에 유해한 2 차 생성물을 생성할 가능성이 있 는 것으로 보고되고 있다. ${ }^{5-6}$ 현재 실내공기 중 휘발성 유기화합물을 검출하기 위한 분석법은 활성탄이나 고 분자흡착제(Tenax TA)와 같은 물질이 충전된 고체 흡 착관에 휴대용 펌프로 강제 흡입을 통한 시료채취 (active sampling) ) $^{7-8}$ 후 열탈착(thermal desorption) 또는 확산을 통한 시료채취(passive sampling) ${ }^{9-10}$ 후 용매탈 착(solvent desorption)하여 $\mathrm{GC} / \mathrm{MS}$ 로 정량하는 분석법 이 대표적이며 시료채취 시 이동과 보관이 편리하며 많은 시료를 동시에 분석할 수 있는 장점이 있어 캐 니스터 ${ }^{11}$ 나 테들라 백에 직접 공기시료를 채취하는 방 법에 비해 일반적으로 더 많이 이용되고 있다. 이러한 열탈착 분석법은 표준물질이 흡착된 고체 흡착관으로 검량하여 기체상 시료가 흡착된 시료흡착관을 정량하 는 외부기준물법(External standard method)을 이용하
기 때문에 정확한 고체 흡착관의 제조가 매우 중요하 다. 현재 국내 - 외의 표준시험방법에서 기체상 표준물 질을 이용한 고체 흡착관 제조방법과 액체상 표준물 질을 이용한 고체 흡착관 제조방법을 제시하고 있으 며 이러한 고체 흡착관 제조방법을 Table 1에 요약하 여 나타내었다. ${ }^{12-15}$ 기체상 표준물질을 이용하는 방법 의 경우 $\mathrm{EPA}$ 의 TO-17 method에서는 표준가스를 기 체 주입용 루프에 취하여 6-port valve를 이용하여 흡 착관에 주입하는 방식을 제시하고 있으며 ISO 160006 에서는 일정한 농도수준으로 제조된 표준대기를 시 료 펌프를 이용하여 흡착관에 주입하는 방법을 제시 하고 있다. ${ }^{2}$ 액체상 표준물질을 이용한 제조방법의 경우 $\mathrm{GC}$ 의 시료주입장치를(Injector) 이용하거나 액체 상 표준물질의 기화가 가능한 ATIS (absoption tube injection system)를 이용하여 고체 흡착관을 제조하는 방법을 제시하고 있다. 이러한 표준물질을 이용한 고 체 흡착관 제조방법에 대한 상세한 조건이 명확하게 제시되지 않아 분석자의 숙련도 및 표준물질의 취급 방법 등에 의해 오차가 발생할 가능성이 있으며 액체 상 표준물질을 이용한 고체 흡착관 제조방법의 경우 기화시키기 위하여 열원을 유지시켜 주는 장치가 필 요하기 때문에 추가적인 비용이 발생한다. 따라서 실 내공기 중 휘발성 유기화합물의 정확한 정량분석을 위한 경제적이고 신뢰할 수 있는 고체 흡착관 제조방 법을 제시할 필요가 있다.

본 연구에서는 실내공기질 규제대상물질인 벤젠, 톨 루엔, 에틸벤젠, 자일렌, 스타일렌을 대상으로 하여 실 온에서의 액체상 표준물질을 이용한 고체 흡착관 제 
Table 1. Comparison of standard preparation methods between gas phase standard and liquid phase standard

\begin{tabular}{|c|c|c|}
\hline Methods & Gas phase standards & Liquid phase standards \\
\hline \multirow[b]{2}{*}{ TO- $17^{\mathrm{a}}$} & Gas sampling volume (GSV) loop & GC Injector (Packed Column) \\
\hline & $\begin{array}{l}\cdot \text { Volume : } 0.5 \sim 5 \mathrm{~mL} \\
\cdot \text { Purge : He (at least ten times the loop vol- } \\
\text { ume) }\end{array}$ & $\begin{array}{l}\text { Volume : } 0.1 \sim 10 \mu \mathrm{L} \\
\text { - Temp. : Unheated or } 50{ }^{\circ} \mathrm{C} \text { (analytes less vol- } \\
\text { atile than } \mathrm{n}-\mathrm{C}_{12} \text { ) } \\
\text { - Purge : } 100 \mathrm{~mL} / \mathrm{min}(\mathrm{He})\end{array}$ \\
\hline \multirow[b]{2}{*}{ ISO $16000-6^{b}$} & Sampling pump & GC Injector \\
\hline & $\begin{array}{l}\text { - Volume : } 0.1 \mathrm{~L} \sim 4 \mathrm{~L}, 10 \mathrm{~L} \text { (standard atmo- } \\
\text { spheres equivalent to } 100 \mu \mathrm{g} / \mathrm{m}^{3} \text { ) } \\
\text { - Purge : Standard atmosphere (ISO } 1641 \text { and } \\
\text { ISO 6145) }\end{array}$ & $\begin{array}{l}\text { - Volume : } 1 \sim 5 \mu \mathrm{L} \\
\text { - Temp. : No conditions } \\
\text { - Purge : } 100 \mathrm{~mL} / \mathrm{min}\left(\mathrm{He}, \mathrm{Ar}, \mathrm{N}_{2}\right), 5 \mathrm{~min}\end{array}$ \\
\hline \multirow[b]{2}{*}{$\begin{array}{l}\text { Korean Standard method for } \\
\text { the Examination of Indoor } \\
\text { Air Quality }\end{array}$} & No conditions & GC Injector or ATIS ${ }^{c}$ \\
\hline & $\begin{array}{l}\cdot \text { Volume : No conditions } \\
\text { - Purge : } 100 \mathrm{~mL} / \mathrm{min}\left(\mathrm{He}, \mathrm{Ar}, \mathrm{N}_{2}\right)\end{array}$ & $\begin{array}{l}\text { Volume : } 1 \sim 5 \mu \mathrm{L} \\
\text { Temp. : Vaporization at } 200{ }^{\circ} \mathrm{C} \\
\text { - Purge : } 100 \mathrm{~mL} / \mathrm{min}(\mathrm{He}, \mathrm{Ar}, \mathrm{N} 2), 5 \mathrm{~min}\end{array}$ \\
\hline \multirow[b]{2}{*}{$\begin{array}{l}\text { Korean Standard method for } \\
\text { the Examination of odor }\end{array}$} & Gas diluter & ATIS \\
\hline & $\begin{array}{l}\text { - Volume : No conditions } \\
\text { - Purge : } \mathrm{N}_{2} \text { or } \mathrm{He}\end{array}$ & $\begin{array}{l}\cdot \text { Volume : No conditions } \\
\text { - Temp. : Vaporization at } 70{ }^{\circ} \mathrm{C} \\
\text { - Purge : } 50 \sim 100 \mathrm{~mL} / \mathrm{min}\left(\mathrm{N}_{2}, \mathrm{He}\right)\end{array}$ \\
\hline
\end{tabular}

aTO-17 : Determination of Volatile Organic Compounds in Ambient Air Using Active sampling onto Sorbent Tubes, U.S. EPA, 1997. ${ }^{b}$ ISO 16000-6 : Determination of volatile organic compounds in indoor and test chamber air by active sampling on TenaxTA sorbent, thermal desorption and gas chromatography using MS/FID, 2004

${ }^{c}$ ATIS : Absorption tube injection system

조방법을 확립하고자 하였다. 또한 기체상 표준물질을 이용한 고체 흡착관 제조방법과 비교하여 두 제조방 법 간의 상관성을 규명하고 이를 실제 환경시료에 적 용하였다.

\section{2. 실 험}

\section{1. 시약 및 기구}

기체상 표준물질은 Supelco사의 TO-14 기체 표준물 질로써 42 종의 $\mathrm{VOCs}$ 가 각각 질소가스에 $1 \mathrm{ppm}$ (moles base)으로 제조된 것을 사용하였으며 액상 표 준물질은 Supelco사의 고농도 실내공기 표준물질로써 메탄올(97\%)에 50 종의 VOCs가 $1000 \mathrm{ppm}$ 으로 제조 된 표준물질을 사용하였다. 표준물질의 희석 시 사용 한 바이알은 Supelco사의 스크류 캡과 시리콘 격막 (silicon septa)로 구성된 $4 \mathrm{~mL}$ 바이알을 사용하였다. 표준물질제조와 시료주입에 사용한 실린지는 기체 주 입용 실린지(Hemilton)로써 용량은 $250 \mu \mathrm{L}$ 를 사용하 였다. 메탄올은 Fisher사의 HPLC 등급시약을 사용하 였다. 고체 흡착관은 유리관(3.5" × 1/4" O.D, Supelco) 에 Tenax TA가 $200 \mathrm{mg}$ 이상 충진된 고체 흡착관을
사용하였다. 본 연구에서 사용한 표준물질 주입장치는 Fig. 1과 같이 구성하였다. Purge 가스는 고순도 헬 륨가스 $(99.999 \%)$ 를 사용하였으며, 질량 유속계를 이 용하여 $100 \mathrm{~mL} / \mathrm{min}$ 으로 정밀하게 유속을 조절하였 다. T자 연결관(Swagelok)과 디스크 격막을 이용하 여 시료주입구를 제작 하였으며 테프론 페럴을 이용 하여 흡착관을 연결하였다. 또한 후단에 로터메타를 연결하여 흡착관을 통하여 나오는 유속을 재확인 하 였다.

\section{2. 분석방법}

저온농축장치는 TD-20 (Shimadzu, Japan)으로 Tenax $\mathrm{TA}(50 \mathrm{mg})$ 가 충진된 전기적 방식의 극저온트랩으로 구성된 것을 사용하였으며 흡착관을 Kalez-O ring으로 기밀시켜 탈착된 시료가 트랩으로 도입되도록 하였다. 기체크로마토그래프와 질량분석계는 GC-2010과 GGMS-QP2010plus (Shimadzu, Japan)로 구성된 것을 사 용하였다. 운반가스는 $99.999 \%$ 고순도 헬륨가스를 사 용하였으며 inline combination gas purifier를 사용하여 불순물을 제거하였다. 열탈착조건은 극저온트랩을 -20 ${ }^{\circ} \mathrm{C}$ 로 냉각하고 흡착관을 $330{ }^{\circ} \mathrm{C}$ 에서 $100 \mathrm{~mL} / \mathrm{min}$ 으로 

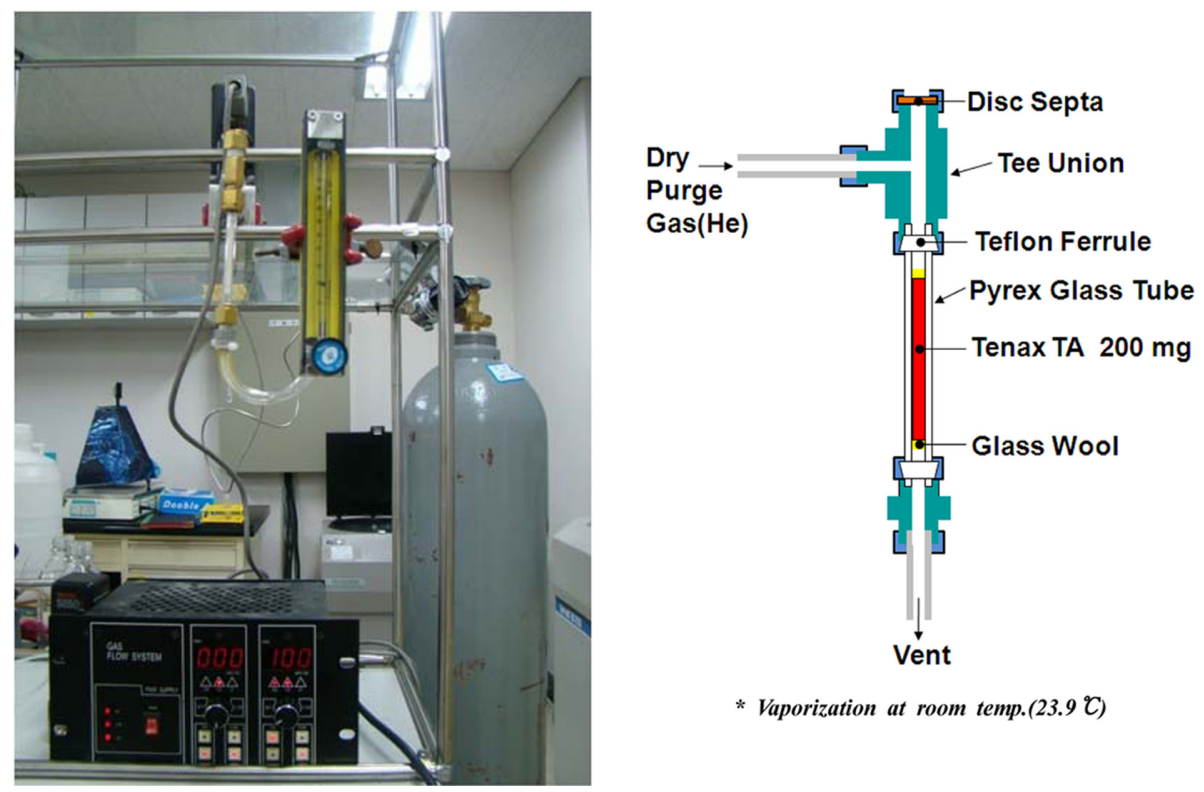

Fig. 1. Photograph of standard injection system for standard sorbent tube.

5 분간 퍼지하여 탈착된 시료를 응축(refocussing)시키고 극저온트랩을 $320^{\circ} \mathrm{C}$ 로 $20 \mathrm{~min}$ 간 가열하여 응축된 시료 를 재 탈착하였다. 재 탈착된 시료는 비분할주입방식 (splitless)으로 모세관 컬럼으로 주입하도록 하였다. 분리 컬럼은 ZB-624 모세관 컬럼(6\%-Cyano propyl phenyl 94\%-Dimethylpolysiloxane fused-silica, $60 \mathrm{~m} \times 0.25 \mathrm{~mm}$ I.D., $1.4 \mu \mathrm{m}$ film thick ness, Phenomenex, USA)을 사 용하였다. 분석조건으로서 컬럼 내 운반가스의 유속이 $1.1 \mathrm{~mL} / \mathrm{min}$ 로 유지되도록 하였으며 온도프로그램은 40 ${ }^{\circ} \mathrm{C}$ 에서 6 분간 유지한 후 승온율을 $4{ }^{\circ} \mathrm{C} / \mathrm{min}$ 로 하여 180 ${ }^{\circ} \mathrm{C}$ 까지 온도를 상승시키고 다시 승온율을 $20{ }^{\circ} \mathrm{C} / \mathrm{min}$ 로 하여 $250{ }^{\circ} \mathrm{C}$ 까지 온도를 상승시켜 10 분간 유지하였다. 질량분석계의 조건은 이온원(Ion source)의 온도를 200 ${ }^{\circ} \mathrm{C}$, 이온화에너지를 $70 \mathrm{eV}$ 로 고정하여 35 350 amu 범 위의 토막 및 분자이온을 검출하였다.

\section{3. 표준 흡착관 제조방법}

기체상 표준물질을 이용한 표준 흡착관은 퍼지가스 (He)를 $100 \mathrm{~mL} / \mathrm{min}$ 으로 퍼지한 상태에서 기체용 실 린지 로 표준가스를 단계별로 취하여 흡착관에 주입 하여 1 분간 퍼지하여 제조하였으며 표준물질주입 시 실내온도를 측정하여 기록하고 식 (1)을 이용하여 개 별 VOCs의 주입량을 산출하였다. ${ }^{16}$ 액체상 표준물질 은 표준물질의 주입 전 · 후 실린지의 무게를 측정하여
주입량을 산출하는 중량법(gravimetry)을 이용하였으 며 액체상 표준물질을 단계별로 희석 - 제조하여 기체 용 실린지로 실온에서 주입하고 헬륨가스로 퍼지하여 표준 흡착관을 제조하였다. 액체상 표준물질을 이용하 여 제조한 고체 흡착관의 개별 $\mathrm{VOCs}$ 의 주입량은 식 (2)를 이용하여 산출하였다.

$\mathrm{W}(\mathrm{ng})=\frac{\mathrm{C}}{\mathrm{V}_{\mathrm{B}}} \times \mathrm{M} \times \mathrm{V}_{\mathrm{s}}$

$\mathrm{W}$ : 기체상 시료의 총 흡착량 $(\mathrm{ng})$

$\mathrm{C}$ : 시료의 농도 $(\mu \mathrm{mole} / \mathrm{mole})$

$\mathrm{V}_{\mathrm{B}}$ : 희석기체의 부피 (L/mole)

$\mathrm{V}_{\mathrm{S}}$ : 고체흡착관에 주입한 표준가스 부피 $(\mathrm{mL})$

$\mathrm{M}$ : 시료 기체의 몰질량 $(\mathrm{g} / \mathrm{mole})$

$\mathrm{T} \quad$ : 온도 $\left({ }^{\circ} \mathrm{C}\right)$

$\mathrm{W}(\mathrm{ng})=\mathrm{C} \times \frac{\left(\mathrm{SW} \times \mathrm{SW}_{0}\right) / \rho_{0}}{\left[\left(\mathrm{VW}-\mathrm{VW}_{0}\right)+\left(\mathrm{SW}-\mathrm{SW}_{0}\right)\right] / \rho}(2)$

$\mathrm{W}$ : 액체상 표준시료의 총 흡착량 (ng)

$\mathrm{C}$ : 저장 용액의 농도 $(\mathrm{ng} / \mu \mathrm{L})$

$\rho \quad$ : 메탄올 밀도 $(\mathrm{g} / \mathrm{mL})$

$\mathrm{SW}$ : 액체상 표준물질 포함된 실린지 질량 $(\mathrm{g})$

$\mathrm{SW}_{0}$ : 주입 후 실린지만의 질량 $(\mathrm{g})$

$\mathrm{VW}$ : 바이엘과 희석용매 질량 $(\mathrm{g})$ 
$\mathrm{VW}_{0}$ : 바이엘 질량 $(\mathrm{g})$

\section{4. 환경 시료채취}

본 연구에서는 6 개월 미만의 신축 건물과 출고 3 개월 미만의 자동차를 선정하여 최적화된 휘발성 유 기화합물 분석방법을 적용하였다. 신축건물의 실내공 기 시료채취의 경우 실내 공기질 공정시험기준(환경 부)에 준하여 실시하였으며 자동차의 실내 공기시료 의 채취는 JAMA (Japanese Automotive Manufactures Association)법 ${ }^{17}$ 을 이용하여 옥외주차장에서 차량내부 를 30 분간 환기시키고 5 시간 밀폐한 후 시료채취 펌프를 차량내부의 중앙에 위치시키고 고체 흡착관을 연결하여 $100 \mathrm{~mL} / \mathrm{min}$ 으로 30 분간 실내공기 시료를 채취를 하여 차량 실내공기 중 휘발성 유기화합물의 농도를 평가하였다.

\section{3. 결과 및 고찰}

\section{1. 고체 흡착관 열탈착 분석조건 최적화}

휘발성 유기화합물을 분석하기 위하여 Tenax TA 고체 흡착관 탈착과 극저온트랩의 열탈착조건을 조사 하였다. Tenax TA 고체 흡착관에 기체상 표준물질을 주입하여 제조한 표준 흡착관을 조건변화에 따라 4회 반복 분석하여 검출된 피크의 면적값을 비교하여 최 적조건을 조사하였다. 열탈착장치에서 Tenax TA 흡착 관의 탈착 시간, 탈착 유량, 탈착 온도를 조사하여 Fig. 2에 나타내었다. Fig. 2(a)에서 흡착관 탈착 유량 을 $50 \mathrm{~mL} / \mathrm{min}$ 으로 유지하고 탈착 시간을 1 20 분까 지 변화시켜 최적 흡착관 탈착 시간을 조사한 결과, 탈착시간 6 분까지는 7 종 시료 모두 거의 탈착하지 않았다가 8 분부터 서서히 증가하였고 10 분에 가장 높은 탈착률을 나타내었고, 12 분에서부터 탈착률이 다소 감소하였다가 20 분까지 일정한 값을 나타내었 다. 최적 탈착시간은 10 분에서 가장 큰 $\mathrm{TVOCs}$ 피크 면적값을 나타내었고 상대 표준편차(RSD\%) $8.0 \%$ 의 좋은 재현성을 나타냈으며 최적의 흡착관 퍼지가스의 부피는 $500 \mathrm{~mL}$ 로 확인되었다. 본 연구와 동일한 열탈 착/저온농축-GC/MS 분석장치로 $\mathrm{BTEX}$ (벤젠, 톨루엔, 스타일렌 및 자일렌)을 분석한 전 등 ${ }^{20}$ 의 실험에서 $3.6 \sim 40.6 \mathrm{ppb}$ 농도 범위의 $\mathrm{VOCs}$ 에 대한 상대표준편 차는 2.6 12.3\%의 범위를 나타내었고, TVOCs의 평균 $\mathrm{RSD}$ 는 $7.7 \%$ 를 나타낸 것으로 보아 본 연구에서의 재 현성이 타 분석시스템과 비교하였을 때 유의한 차이 가 없는 것으로 판단된다.

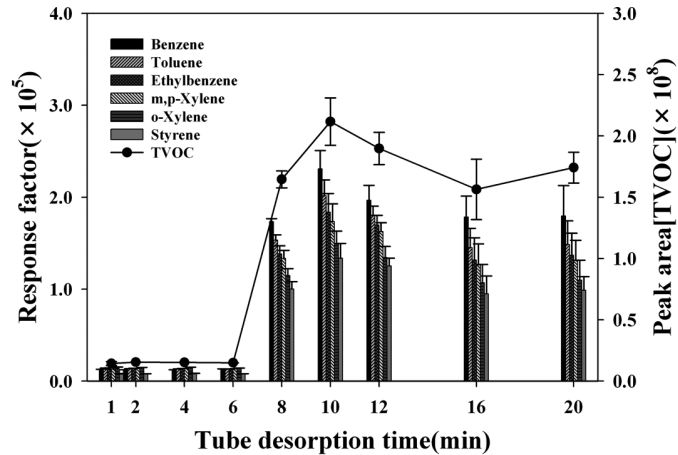

(a)

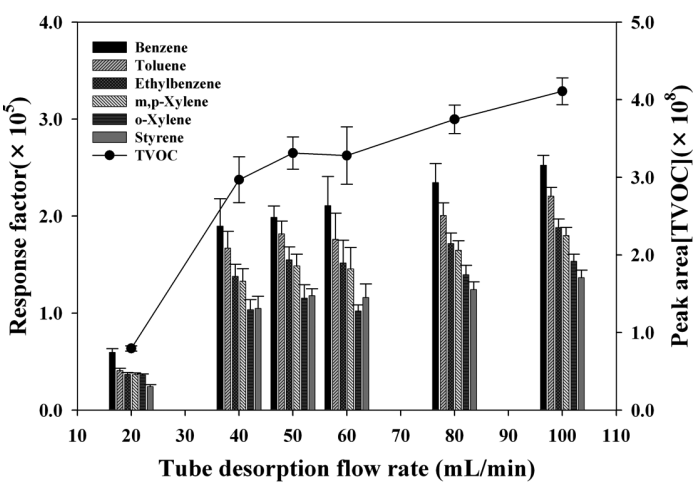

(b)

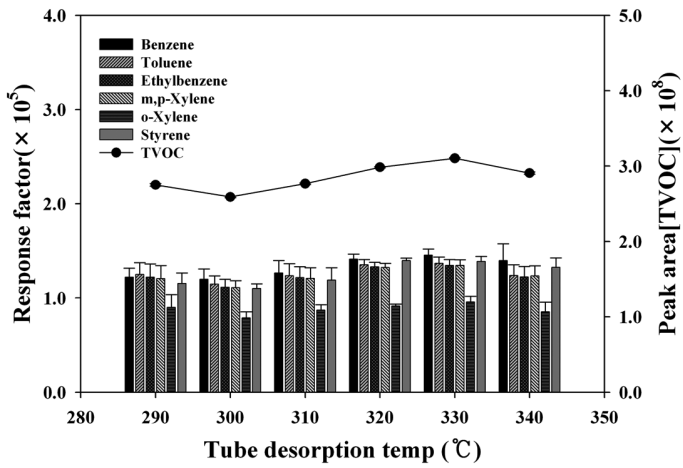

(c)

Fig. 2. Optimization of Tube desorption conditions for analyzing VOCs using thermal desorption unit with TenaxTA sorbent tube; (A) Tube desorption time, (B) Tube desorption flow, (C) Tube desorption temperature.

Fig. 2(b)에서 볼 수 있는 바와 같이 흡착관을 탈착 하기 위한 헬름 가스의 유량을 $20 \sim 100 \mathrm{~mL} / \mathrm{min}$ 로 변 화시키고 탈착시간을 조절하여 헬륨가스의 총 탈착에 사용된 부피를 $500 \mathrm{~mL}$ 로 고정하여 최적탈착 유속을 조사하였다. 헬륨가스의 유속이 $50 \mathrm{~mL} / \mathrm{min}$ 이하에서 는 낮은 TVOCs의 면적을 나타냈으며 $50 \mathrm{~mL} / \mathrm{min}$ 이 


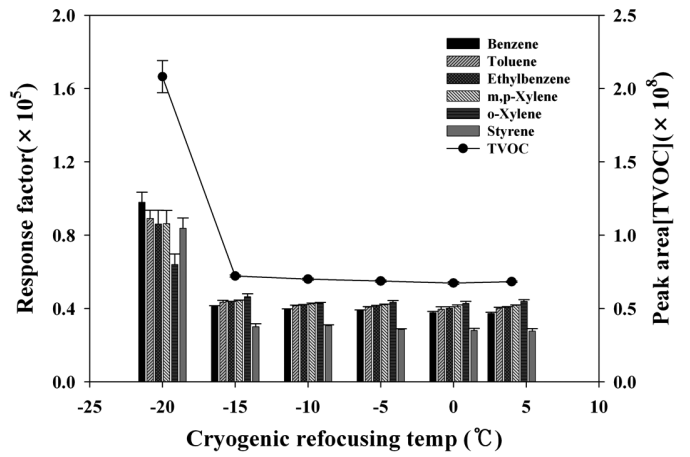

(a)

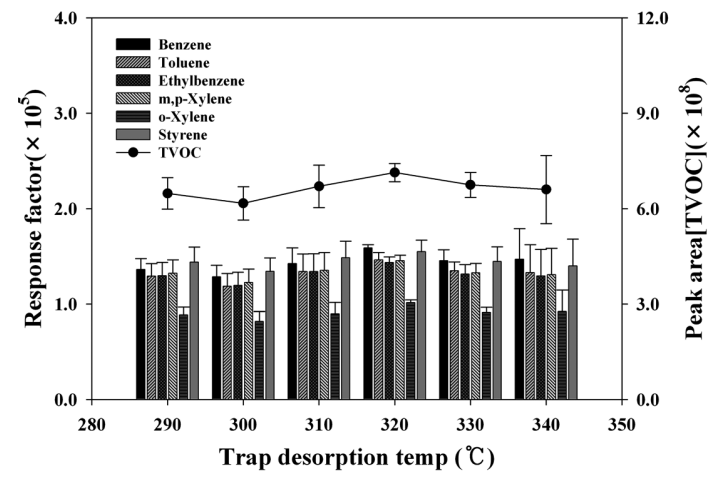

(b)

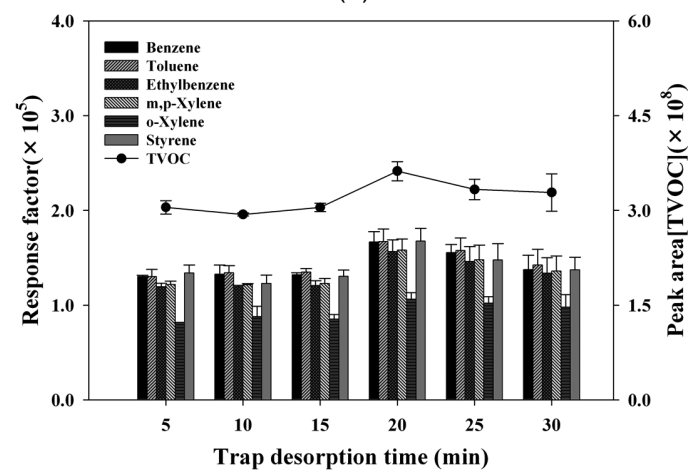

(c)

Fig. 3. Optimization of cryogenic trap desorption conditions for analyzing VOCs using thermal desorption unit with Tenax TA sorbent tube.; (A) Cryogenic refocusing temperature, (B) Trap desorption temperature, (C) Trap desorption time.

상으로 유속을 증가할 경우 TVOCs의 면적값이 계속 증가하는 경향을 나타내었다. 퍼지가스를 $100 \mathrm{~mL} / \mathrm{min}$ 의 유량으로 5 분간 탈착한 것이 가장 큰 TVOCs S 피크 면적값을 나타내었고 상대표준편차 $4.2 \%$ 의 좋은 재현성을 나타냈다. 따라서 흡착된 VOCs를 탈착시키 기 위해 총 $500 \mathrm{~mL}$ 의 헬륨가스를 사용한다고 하였을
때, $50 \mathrm{~mL} / \mathrm{min}$ 유속으로 20 분간 탈착시키는 것보다 는 $100 \mathrm{~mL} / \mathrm{min}$ 유속으로 5 분간 탈착시키는 것이 좀 더 효과적인 탈착방법인 것으로 사료된다. 고체흡착관 의 헬륨기체의 탈착 유속과 탈착시간을 각각 $100 \mathrm{~mL} /$ $\min$ 및 5 분으로 유지한 채 탈착온도를 $290{ }^{\circ} \mathrm{C}$ 에서 $340{ }^{\circ} \mathrm{C}$ 까지 증가시켰을 때 Fig. 2(c)에 나타난 바와 같이 실험한 탈착온도 구간에서 거의 유사한 피크 면 적값을 나타내었으나 $330{ }^{\circ} \mathrm{C}$ 에서 다소 높은 피크 면 적값을 나타내었기에 최적탈착온도는 $330{ }^{\circ} \mathrm{C}$ 로 고정 하여 이후의 실험을 진행하였다.

극저온트랩의 냉각 온도, 탈착 온도 및 탈착 시간 을 조사하여 Fig. 3에 나타냈었다. 극저온 트랩의 온 도는 $4 \sim-20{ }^{\circ} \mathrm{C}$ 까지 변화시켜 $\mathrm{VOCs}$ 를 응축시키기 위한 최적온도를 조사한 결과 TVOCs 피크면적은 4 ${ }^{\circ} \mathrm{C}$ 로부터 온도를 낮출수록 증가하는 경향을 나타내 었으며 $-20{ }^{\circ} \mathrm{C}$ 에서 가장 큰 $\mathrm{TVOCs}$ 면적을 나타내 었고 $5.7 \%$ 로 좋은 재현성을 나타내었다. 그러나 본 연구에서 사용한 트랩은 냉매를 이용하지 않은 전기 적 방식 극저온트랩으로서 $-20{ }^{\circ} \mathrm{C}$ 이하로 냉각할 경 우 냉각시간이 증가되기 때문에 분석시간을 고려하 여 $-20{ }^{\circ} \mathrm{C}$ 로 냉각하는 것이 효율적인 트랩냉각온도 로 판단된다. 또한 트랩온도를 $290 \sim 340{ }^{\circ} \mathrm{C}$ 범위에 서 변화시킨 결과, $320{ }^{\circ} \mathrm{C}$ 에서 최대 $\mathrm{TVOCs}$ 면적값 을 나타냈으며 각각의 화합물의 감응인자도 $6.2 \%$ 의 좋은 재현성을 나타냈었다. 트랩 탈착시간을 최대 5 30 분까지 변화시켜 확인한 결과 트랩탈착시간을 20 분으로 하였을 때 최대 TVOCs 면적값을 나타내 었으며 상대표준편차율도 $6.2 \%$ 로 좋은 재현성을 나 타내었다.

\section{2. 열탈착 분석조건의 유효성 평가}

휘발성 유기화합물을 분석하기 위하여 확립한 열탈 착 분석방법에 대하여 유효성을 평가하였다. Benzene 외 6종의 $\mathrm{VOCs}$ 에 대하여 회수율(recovery)과 재현성 (reproducibility)을 측정하여 정확성(accuracy)과 정밀 성(precision)을 평가하였고 검출한계(MDL, method detection limit)를 산출하여 Table 3 에 나타내었다. ${ }^{18}$ 본 연구에서 대상으로 한 $\mathrm{VOCs}$ 의 회수율은 $95 \sim 105 \%$ 의 범위를 나타내었으며, 재현성은 $0.3 \sim 7.7 \%$ 의 범위를 보이고 있는데, 전 등 ${ }^{19}$ 이 실험한 정밀성과 유사한 범 위를 나타내었다. 박 등 ${ }^{20}$ 에 의한 바닥재로부터 VOCs 방출 특성 연구에서 열탈착의 회수율 범위가 벤젠 $92.4 \%$ 에서 에틸벤젠의 $120.2 \%$ 까지 넓은 회수 율 범위를 나타낸 것으로 판단해 볼 때 본 연구에서 
Table 2. Analytical conditions of TDU and GC/MS

\begin{tabular}{|c|c|c|c|}
\hline \multicolumn{2}{|c|}{$\begin{array}{l}\text { Automated Thermal Desorber: } \\
\text { TD-20 (Shimazdu, Japan) }\end{array}$} & \multicolumn{2}{|c|}{$\begin{array}{c}\text { Gas Chromatograph / Mass Stpectometer: } \\
\text { GC2010/GCMS-QP2010plus (Shimazdu, Japan) }\end{array}$} \\
\hline Parameters & Conditions & Parameters & Conditions \\
\hline Tube desorption temp. & $330{ }^{\circ} \mathrm{C}$ & Injection mode & Splitless \\
\hline Tube desorption flow and time & $100 \mathrm{~mL} / \mathrm{min}, 5 . \mathrm{min}$ & $\begin{array}{l}\text { Sampling time } \\
\text { Column flow }\end{array}$ & $\begin{array}{l}1 \mathrm{~min} \\
1.1 \mathrm{~mL} / \mathrm{min}\end{array}$ \\
\hline Cryogenic refocussing temp. & $-20^{\circ} \mathrm{C}$ & GC column & ZB-624 $(60 \mathrm{~m} \times 0.25 \mathrm{~mm} \times 1.4 \mu \mathrm{m})$ \\
\hline Trap desorption temp. & $320^{\circ} \mathrm{C}$ & $\begin{array}{l}\text { Initial temperature } \\
\text { 1st. Temp. ramp rate }\end{array}$ & $\begin{array}{l}40{ }^{\circ} \mathrm{C}(6 \mathrm{~min}) \\
4{ }^{\circ} \mathrm{C} / \min \left(40 \sim 180{ }^{\circ} \mathrm{C}\right)\end{array}$ \\
\hline Trap desorption time & $20 \mathrm{~min}$ & $\begin{array}{l}\text { 2nd Temp. ramp rate } \\
\text { Final temperature }\end{array}$ & $\begin{array}{l}20{ }^{\circ} \mathrm{C} / \mathrm{min}\left(180 \sim 250{ }^{\circ} \mathrm{C}\right) \\
250{ }^{\circ} \mathrm{C}(10 \mathrm{~min})\end{array}$ \\
\hline Trap packed material & $50 \mathrm{mg}$ Tenax TA & Interface temperature & $250{ }^{\circ} \mathrm{C}$ \\
\hline Valve temperature & $280{ }^{\circ} \mathrm{C}$ & $\begin{array}{l}\text { Ionization method } \\
\text { Ionsource temperature }\end{array}$ & $\begin{array}{l}\text { EI (Quadrople) } \\
200{ }^{\circ} \mathrm{C}\end{array}$ \\
\hline Transfer line temp. & $280{ }^{\circ} \mathrm{C}$ & $\begin{array}{l}\text { Ionization energy } \\
\text { Mass range }\end{array}$ & $\begin{array}{l}70 \mathrm{eV} \\
35 \sim 350 \mathrm{amu}\end{array}$ \\
\hline
\end{tabular}

Table 3. Validation of optimized thermal desorption condition for analyzing VOCs in this study

\begin{tabular}{lccc}
\hline \hline \multicolumn{1}{c}{ VOCs } & $\begin{array}{c}\text { Recovery } \\
(\%)\end{array}$ & $\begin{array}{c}\text { RSD } \\
(\%)^{\mathrm{a}}\end{array}$ & $\begin{array}{c}\text { MDL } \\
\left(\mu \mathrm{g} / \mathrm{m}^{3}\right)^{\mathrm{b}}\end{array}$ \\
\hline Benzene & 95.8 & 6.9 & 0.17 \\
Toluene & 102.0 & 7.7 & 0.27 \\
Ethylbenzene & 101.9 & 1.4 & 0.05 \\
m, p-Xylene & 103.2 & 0.6 & 0.02 \\
o-Xylene & 105.5 & 0.3 & 0.01 \\
Styrene & 102.2 & 1.1 & 0.04 \\
\hline
\end{tabular}

${ }^{a} \mathrm{RSD}$ (relative standard deviation) : reproducibility $(\mathrm{n}=4)$

${ }^{\mathrm{b}} \mathrm{MDL}$ (method detection limit) : MDL $=\mathrm{SD} \times \mathrm{t}$-value $(\mathrm{n}=4$, $\alpha=0.01$ )

의 회수율이 $100 \pm 5 \%$ 이내에 분포한다는 것은 본 분 석시스템에 대한 정확성이 높고 시스템이 안정적인 것을 알 수 있다. 또한 검출한계 $(\mathrm{MDL})$ 는 $3 \sigma$ 법으로 고려하였을 때 $\mathrm{o}$-자일렌의 $0.01 \mu \mathrm{g} / \mathrm{m}^{3}$ 에서부터 톨루 엔의 $0.27 \mu \mathrm{g} / \mathrm{m}^{3}$ 까지 범위를 나타내었고, 이 값은 김 등 ${ }^{2}$ 이 $\mathrm{VOCs}$ 측정을 위해 개발한 열탈착/저온농축$\mathrm{GC} / \mathrm{FID} / \mathrm{FPD}$ 에 의한 검출한계(IDL)에 비교해 볼 때 거의 유사하거나 10 배 정도 더 낮은 검출한계를 나 타내었다.

\section{3. 액상 표준물질을 이용한 고체 흡착관 제조 방법 확립}

액상 표준물질을 기체용 실린지로 $10 \mu \mathrm{L}$ 를 취하여 표준물질 주입장치에 주입하고 헬륨가스를 $100 \mathrm{~mL} /$

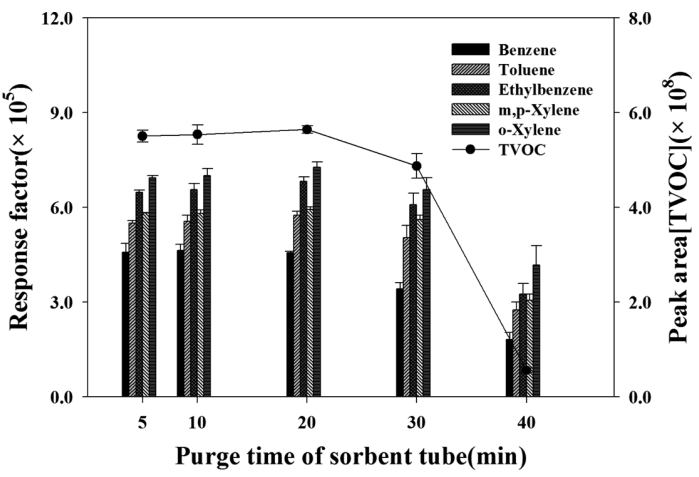

Fig. 4. Variation of TVOCs peak area and response factors with purge time for preparing standard sorbent tube of VOCs using liquid phase standard.

$\min$ 의 유속으로 최대 40 분까지 퍼지하여 TVOCs의 피크면적과 개별 $\mathrm{VOCs}$ 의 감응인자변화를 조사하여 Fig. 4에 나타내었다. 이때 주입된 액체상 표준물질의 절대량은 $100 \mu \mathrm{g}$ 으로서 박 등22이 $\mathrm{VOCs}$ 분석을 위한 작업용 액체상 표준물질 $10 \mathrm{ppm}$ 을 제조하여 Tenex $\mathrm{TA}$ 흡착관에 주입한 양과 동일한 절대량이며, 안 등 23 에 의한 휘발성 유기지방산 액체상 표준물질 100 $\mathrm{ppm}$ 을 $1 \mu \mathrm{L}$ 주입된 것과 동일한 절대량이었다. 액체 상 표준물질이 주입된 흡착관을 20 분 이상 퍼지할 경우 TVOCs 면적과 개별 VOCs의 감응인자가 감소 하는 경향이 확인되었으며 이는 과량의 퍼지 가스에 의하여 손실이 발생한 것으로 판단된다. 헬륨가스의 퍼지시간을 20 분간 퍼지하였을 때 TVOCs 피크면적 


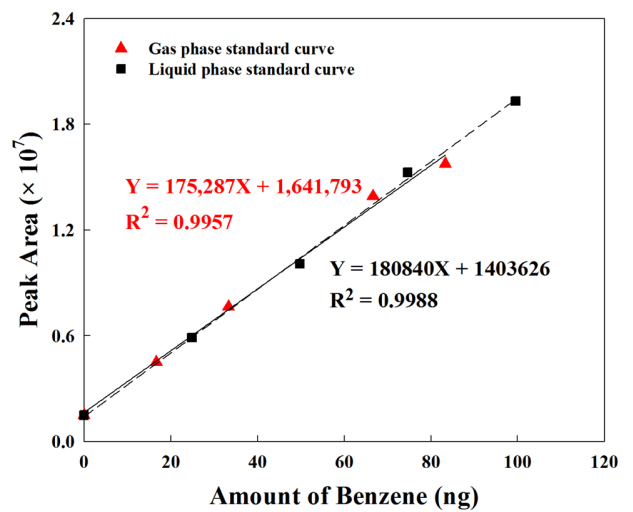

(a) Benzene $(\mathrm{m} / \mathrm{zs}=78)$

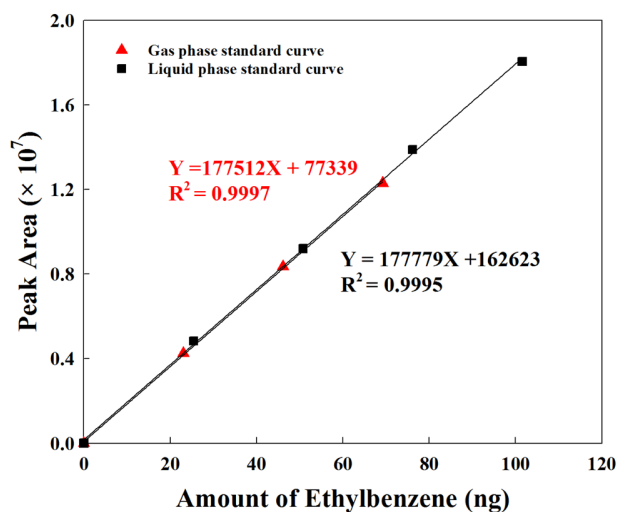

(c) Ethylbenzene $(\mathrm{m} / \mathrm{z}=91)$

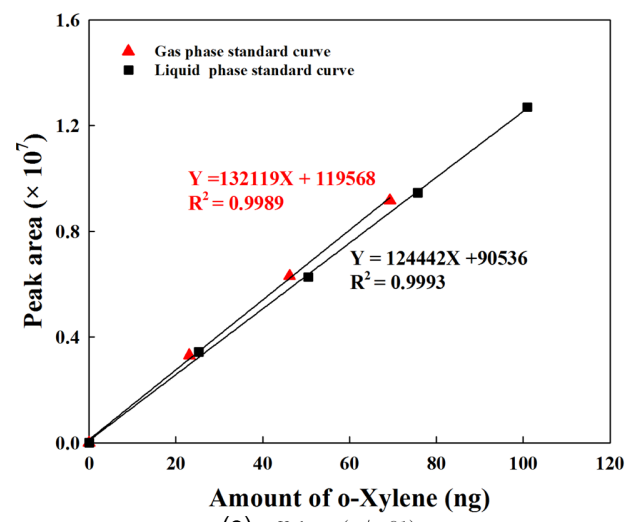

(e) o-Xylene $(\mathrm{m} / \mathrm{z}=91)$

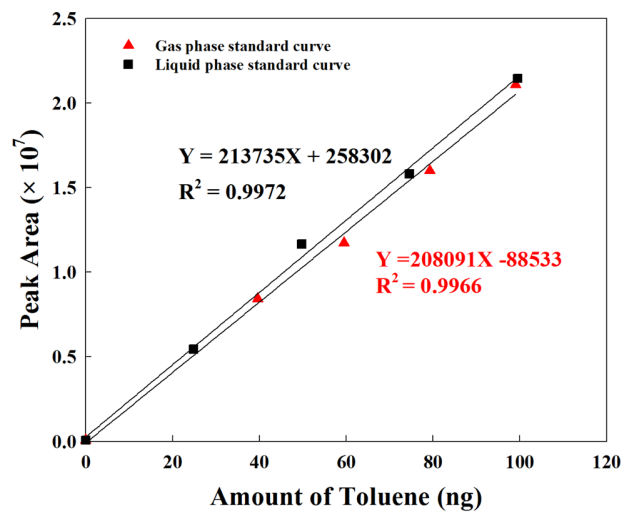

(b) Toluene $(\mathrm{m} / \mathrm{zs}=91)$

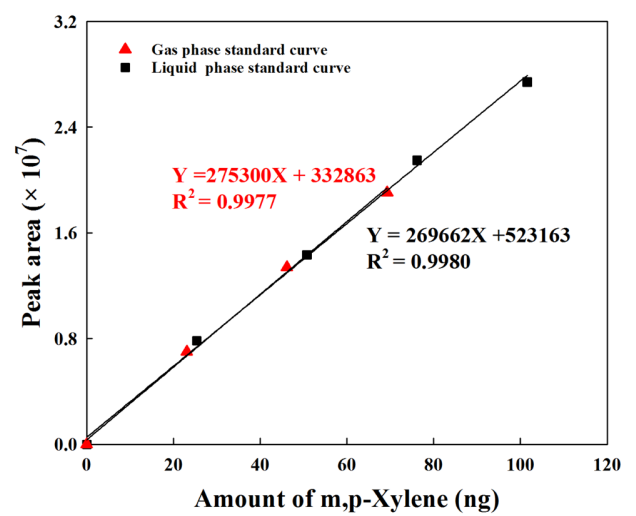

(d) $\mathrm{m}, \mathrm{p}$-Xylene $(\mathrm{m} / \mathrm{z}=91)$

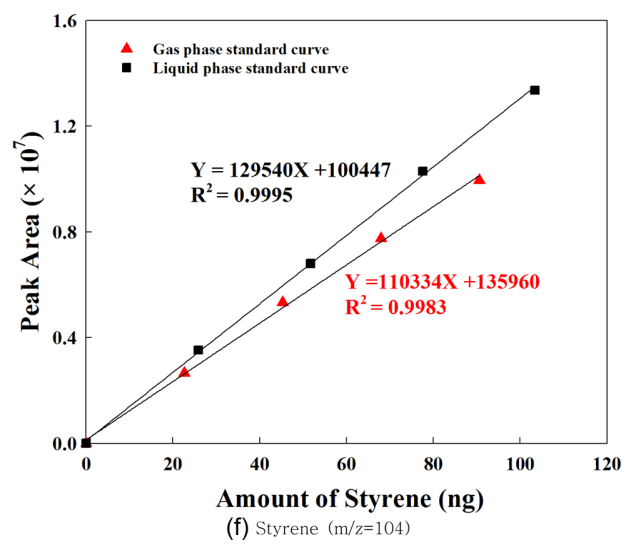

Fig. 5. Comparison of calibration curve between gas phase and liquid phase standard materials.

과 개별 $\mathrm{VOCs}$ 의 감응인자가 최대값을 나타냈다. TVOCs 면적값의 상대표준편차는 $1.4 \%$ 로 좋은 재현 성을 나타내었으며 개별 $\mathrm{VOCs}$ 의 감응인자도 $2.2 \%$ 이 하의 상대표준편차를 나타냈다. 따라서 실온에서 액상 표준물질을 주입하고 20 분간 퍼지하는 것이 최적의 고체 흡착관 제조방법으로 판단된다.

\section{4. 표준 흡착관 제조방법 간 비교}

기상 표준물질을 이용한 고체 흡착관 제조방법과 본 연구에서 최적화한 실온에서의 액체상 표준물질을 이용한 고체 흡착관 제조방법을 비교하기 위하여 벤 젠, 톨루엔, 에틸벤젠, 자일렌, 스타일렌에 대하여 각 각의 검정곡선과 산출된 감응인자를 비교하였다. 기체 
Table 4. Comparison of standard sorbent tube using gas phase and liquid phase standard materials

\begin{tabular}{|c|c|c|c|c|c|c|}
\hline \multirow{2}{*}{ Compounds } & \multicolumn{2}{|c|}{ Gas phase standard } & \multicolumn{2}{|c|}{ Liquid phase standard } & \multirow{2}{*}{ Difference(\%) } & \multirow{2}{*}{$\begin{array}{l}p \text {-Value }{ }^{b} \\
(\alpha=0.01)\end{array}$} \\
\hline & Mean of R.F ${ }^{a}$ & $\operatorname{RSD}(\%)$ & Mean of R.F & $\operatorname{RSD}(\%)$ & & \\
\hline Benzene & 180,278 & 3.7 & 178,151 & 2.8 & 1.3 & 0.60 \\
\hline Toluene & 204,989 & 3.7 & 218,946 & 4.5 & -6.8 & 0.06 \\
\hline Ethylbenzene & 180,860 & 1.8 & 182,813 & 2.9 & -1.1 & 0.61 \\
\hline m,p-Xylene & 144,814 & 4.9 & 142,912 & 5.8 & 1.3 & 0.76 \\
\hline o-Xylene & 137,377 & 4.0 & 127,783 & 4.5 & 7.0 & 0.08 \\
\hline Styrene & 114,599 & 3.1 & 132,523 & 2.3 & -15.6 & 0.0003 \\
\hline
\end{tabular}

${ }^{a}$ Mean of R.F (Response factor, $\left.n=4\right)$ : peak area / amount of each compounds(ng)

${ }^{b} \mathrm{p}$-Value $(\mathrm{n}=4, \alpha=0.01)$ : result calculated by SPSS(ver. 12$)$ program

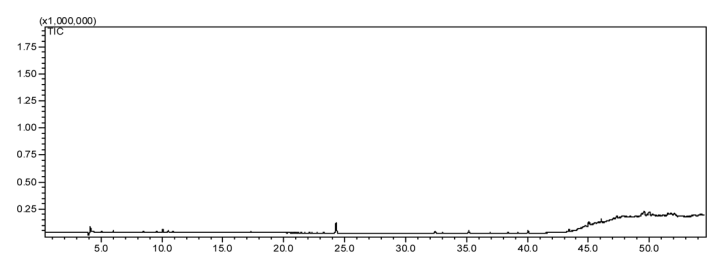

(a) Blank Tube

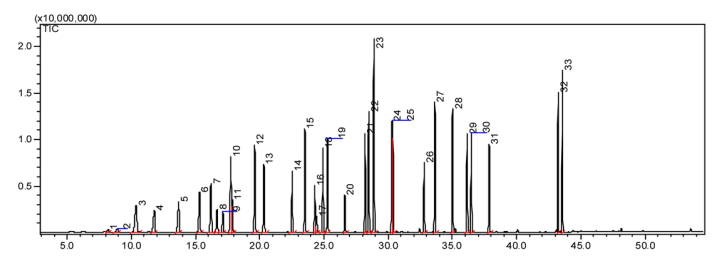

(b) TO-14 gas standard

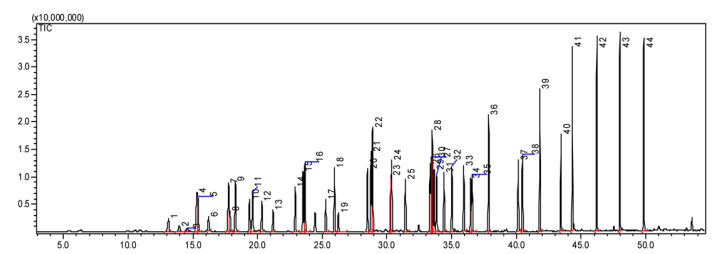

(c) Indoor air Liquid standard

Fig. 6. Total ion chromatogram of VOCs thermal-desorbed from blank and solid sorbent tube by usin TD-GC/ MS. (A) blank (B) TO-14 gas standard: 10, benzene; 15 , toluene; 21 , ethylbenzene; $22, \mathrm{~m}, \mathrm{p}$-xylene; 23 , oxylene; 24, styrene (C) Indoor air liquid standard: 7, benzene; 15 , toluene; 20 , ethylbenzene, $22, \mathrm{~m}$,p-xylene; 23, o-xylene; 24, styrene.

상 표준물질과 액체상 표준물질간의 통계적 유의성을 검정하기 위하여 t-검정을 이용하였다. 액체상과 기체 상의 표준물질로 작성한 개별 VOCs 검정곡선을 비교 하여 Fig. 5에 나타내었다. 기체상과 액체상 표준물질 을 이용한 고체 흡착관 모두 $\mathrm{R}^{2}=0.9957$ 이상의 좋은 상관관계를 나타내었다. 각각의 표준물질 간의 검정곡 선의 기울기를 비교한 결과 벤젠, 톨루엔, 에틸벤젠,
Table 5. Temperature and relative humidity for sampling sites

\begin{tabular}{lccc}
\hline Site & Floor & $\begin{array}{c}\text { Temperature } \\
\left({ }^{\circ} \mathrm{C}\right)\end{array}$ & $\begin{array}{c}\text { R. Humidity } \\
(\%)\end{array}$ \\
\hline B-1 & 6 & 28.9 & 71 \\
B-2 & 1 & 25.0 & 75 \\
C-1 & 18 & 28.6 & 69 \\
C-2 & 3 & 27.3 & 64 \\
D & 3 & 27.9 & 72 \\
Vehicle & - & 31.9 & 70 \\
\hline
\end{tabular}

자일렌의 경우 $0.1 \%$ (에틸벤젠) $6.0 \%$ (o-자일렌) 수준 의 차이를 나타냈으나 스타일렌의 경우 액체상 표준 물질의 기울기가 기체상 표준물질에 비해 $17.4 \%$ 증가 된 기울기를 나타내었다. 또한 각 화합물의 감응인자 를 비교한 결과에서도 스타일렌의 경우 액체상 표준 물질의 평균 감응인자가 기체상에 비해 $15.6 \%$ 증가된 감응인자를 나타내었으나 스타일렌을 제외한 나머지 화합물의 경우 $1.1 \%$ (에틸벤젠) $7.0 \%$ (o-자일렌)로 $10 \%$ 미만의 차이를 나타내었다. 감응인자를 이용한 t-검정 을 실시한 결과에서도 벤젠, 톨루엔, 에틸벤젠, 자일렌 의 $\mathrm{p}$-값은 0.06 0.76 ( $>\alpha=0.01)$ 로 나타나 유의수준을 고려하였을 때 기체상 표준물질과 액체상 표준물질 간에는 차이가 없는 것으로 확인되었다. 그러나 스타 일렌의 경우 $\mathrm{p}$-값이 $0.0003(<\alpha=0.01)$ 로 나타나 기체 상 표준물질과 액체상 표준물질 간의 차이가 있는 것 을 통계적으로 확인하였다. 이러한 경향성은 스타일렌 이 다른 휘발성 유기화합물(BTEX)에 비해 증기압이 낮기 때문에 고압의 가스용기 보관 시 응축되어 손실 이 발생할 가능성이 있으며 고체 흡착관 제조를 위하 여 기체용 실린지나 테들라 백을 이용하는 과정에서 스타일렌이 매질효과(matrix effect)로 인한 흡착 또는 반응에 의해 손실이 발생한 것으로 판단된다. 22,24 
Table 6. Concentrations of TVOCs and individual VOCs for several sites in indoor air $\left(\mu \mathrm{g} / \mathrm{m}^{3}, 25^{\circ} \mathrm{C}\right)$

\begin{tabular}{|c|c|c|c|c|c|c|c|}
\hline \multirow[b]{2}{*}{ Compounds } & \multicolumn{2}{|c|}{ B } & \multicolumn{2}{|c|}{$\mathrm{C}$} & \multirow{2}{*}{ D } & \multirow{2}{*}{ Vehicle } & \multirow{2}{*}{ Guideline $^{\mathrm{a}}$} \\
\hline & $18^{\text {th }}$ floor & $3^{\text {rd }}$ floor & $6^{\text {th }}$ floor & $1^{\text {st }}$ floor & & & \\
\hline Benzene & N.D & 0.81 & N.D & 0.47 & N.D & N.D & 30 \\
\hline Toluene & 106.01 & 63.83 & 117.68 & 76.08 & 179.88 & 32.01 & 1000 \\
\hline Ethylbenzene & 22.92 & 2.50 & 12.17 & 5.93 & 47.44 & 3.01 & 360 \\
\hline m,p-Xylene & 9.91 & 1.53 & 10.56 & 5.00 & 2.15 & 3.57 & 700 \\
\hline o-Xylene & 7.34 & 1.08 & 8.52 & 4.57 & 1.95 & 3.37 & 700 \\
\hline Styrene & 103.76 & 26.89 & 110.59 & 15.17 & 39.77 & 2.79 & 300 \\
\hline TVOCs s & 437.9 & 209.4 & 411.6 & 187.6 & 604.2 & 586.3 & $400^{\mathrm{b}}$ \\
\hline
\end{tabular}

${ }^{a}$ IAQ regulation for multidwelling buildings over 100 units established on January 1, 2006 in Korea

${ }^{\mathrm{b}} \mathrm{IAQ}$ regulation for TVOCs $\mathrm{s}$ in public use facilities such as medical and day care center etc.

따라서 기체상 표준물질을 기체용 실린지 로 취하 여 고체 흡착관을 제조하여 시료를 정량할 경우 액체 상 표준물질을 이용한 정량결과에 비해 증가된 결과 를 산출하여 실내공기 중 스타일렌의 농도가 실제농 도보다 과대평가될 가능성이 있기 때문에 본 연구에 서 제시한 실온에서의 액체상 표준물질을 이용한 고 체 흡착관을 제조방법을 이용할 경우, 스타일렌과 같 은 반응성이 있는 휘발성 유기물질의 고체 흡착관 제 조 시 오차를 배제할 수 있을 것으로 판단된다. Fig. 6에서는 세정된 고체 흡착관의 바탕 크로마토그램과 $\mathrm{VOCs}$ 기체상 표준물질 및 액체상 표준물질이 고체흡 착관에 흡착되었다가 탈착된 $\mathrm{GC} / \mathrm{MS}$ 의 총이온크로마 토그램(TIC)를 나타내었다.

\section{5. 환경시료 분석에 적용}

시료채취 당시의 온도, 습도 측정결과를 Table 5 에 나타내었다. 거주공간의 온도는 실온영역을 만족하였 으며 차량의 경우 실온보다는 높았으나 측정방법의 온도기준 범위 내로 측정되었다. 액체상 표준물질을 이용하여 제조한 고체 흡착관을 이용하여 휘발성 유 기화합물을 정량한 결과를 Table 6에 나타내었다. TVOCs 분석결과 $\mathrm{B}$ 지역과 $\mathrm{C}$ 지역의 고층의 시료는 평균 $437.9 \mu \mathrm{g} / \mathrm{m}^{3}$ 와 $411.6 \mu \mathrm{g} / \mathrm{m}^{3}$ 으로 나타났으며 저 층의 TVOCs 농도 보다 약 2 배 높게 검출되었다. D 지역은 평균 TVOCs 농도 $604.2 \mu \mathrm{g} / \mathrm{m}^{3}$ 로 측정되었으 며 다중이용시설 실내공기질 권고기준 $\left(500 \mu \mathrm{g} / \mathrm{m}^{3}\right)$ 을 적용하였을 때 1.2 배 초과하는 것으로 나타났다. 개 별 휘발성 유기화합물(벤젠, 톨루엔, 에틸벤젠, m,p-자 일렌, 스타일렌)은 모든 시료에서 검출되었으나 신축 공동주택 실내공기질 권고기준을 초과하지 않은 것으 로 나타났다. 자동차 실내공기의 경우 TVOCs는 586.29 $\mu \mathrm{g} / \mathrm{m}^{3}$ 로 나타났으며 개별 휘발성 유기화합물은 낮은
수준으로 검출되었다.

이 외에도 $\mathrm{GC} / \mathrm{MS}$ 에 의해 확인된 물질로서 아세톤, 메틸에틸케톤, 메틸이소부틸케톤(MIBK), 알데하이드 류 화합물(헥산알, 노난알, 데칸알), 탄화수소류 화합 물(도데칸, 트라이데칸, 테트라데칸, 펜타데칸, 헥사데 칸), 알파 및 베타-피넨( $\alpha$-pinene, $\beta$-pinene) 등이 검출 되었으나 본 연구에서는 BTEX를 정량하는 방법에만 초점을 두었으므로 이들을 정량하지는 않았다. 이중 탄화수소류는 카펫타일 또는 고무타일로부터 용출되 는 것으로 알려져 있으며, 피넨은 테르펜류의 일종으 로 실내 내장재로 쓰인 소나무 재질의 목재로부터 방 출된 것으로 판단되는데, 실외 대기 중에서는 온도와 햇빛 강도에 따라 나무로부터 피넨의 방출량이 달라 지고, 오존과 반응하여 알데하이드류 화합물을 생성시 켜 2차 대기오염물질로 작용한다. ${ }^{20}$ 또한 일반 벽지에 서는 톨루엔을 비롯한 에틸벤젠, 자일렌이 다량 방출 되지만, 천연벽지에서는 톨루엔의 방출량이 감소하는 대신 $\mathrm{n}$-부탄올 및 $\mathrm{n}$-테트라데칸과 같은 화합물들이 검 출되는 것으로 보고되고 있다..$^{25}$

\section{4. 결 론}

휘발성 물질을 정량하기 위해서 고가의 표준기체를 반드시 사용해야 하는지에 대한 의문을 풀기 위해서 액체상 표준물질과의 비교를 통해서 이런 의문에 대 한 해답을 찾고자 본 연구를 수행하였다. 고체 흡착관 을 이용한 휘발성 유기화합물을 정량하기 위하여 열 탈착 분석조건의 최적화 및 액체상표준물질을 이용한 실온에서의 고체 흡착관 제조방법을 확립하여 기체상 및 액체상표준물질을 이용한 고체 흡착관의 상관성을 비교한 결과를 요약하면 다음과 같다.

1. Tenax TA흡착관의 이용하여 휘발성 유기화합물 
을 분석하기 위한 열탈착조건은 다음과 같다. 흡착관 탈착 온도는 $330{ }^{\circ} \mathrm{C}$ 이며 흡착관 탈착유량 $100 \mathrm{~mL} /$ $\min$ 로 5 분 동안 탈착하여 $-20{ }^{\circ} \mathrm{C}$ 로 극저온트랩에서 응축하여 $320{ }^{\circ} \mathrm{C}$ 에서 20 분간 재 탈착하는 것을 최적 분석조건으로 확립하였다.

2. 실온에서 액체상표준물질을 $1 \sim 10 \mu \mathrm{L}$ 범위로 주 입하고 헬륨 가스를 $100 \mathrm{~mL} / \mathrm{min}$ 으로 20 분간 퍼지하 는 것이 최적의 고체 흡착관 제조방법이었다.

3. 기체상 표준물질을 이용한 고체 흡착관 제조방법 과 실온에서 액체상 표준물질을 이용한 고체 흡착관 제조방법을 비교한 결과 벤젠, 톨루엔, 에틸벤젠, $\mathrm{o}$, $\mathrm{m}, \mathrm{p}$-자일렌의 경우 상대오차 $7.0 \%$ 이하의 차이를 나 타내었으나 스타일렌의 경우 $15.6 \%$ 의 상대오차를 나 타내었다. t-검정을 수행한 결과, 벤젠, 톨루엔, 에틸벤 젠, $\mathrm{o}, \mathrm{m}, \mathrm{p}$-자일렌의 경우 고체 흡착관 제조방법 간 에 차이가 없는 것으로 나타났으나 스타일렌의 경우 유의수준 $(\mathrm{a}=0.01)$ 을 고려하였을 때 두 고체 흡착관 제 조방법 간에 차이가 있는 것으로 나타났다.

4. 실온에서 액체상 표준물질을 이용한 표준흡착을 분석하여 실제 실내공기질 중 휘발성유기화합물의 농 도를 평가한 결과, 신축기숙사의 실내공기시료 6 개 중 1 개의 장소에서 다중이용시설 실내공기질 권고기 준을 1.2 배 초과하였다. 차량내부의 실내공기를 측정 한 결과 $586.29 / \mathrm{m}^{3}$ 로 측정되었다. 벤젠은 1 개 지역 에서 검출되었으나 $1 / \mathrm{m}^{3}$ 이하로 검출되어 신축공동주 택 기준인 $30 / \mathrm{m}^{3}$ 을 초과하지 않았고, 톨루엔과 에틸 벤젠, $\mathrm{m}, \mathrm{p}$-자일렌, 스타일렌등이 모든 시료에서 검출 되었으나 신축공동주택 실내공기질 기준을 초과하지 않은 것으로 확인되었다.

\section{참고문헌}

1. P. J. Franklin, Pediatr. Respir. Rev., 8, 281-286 (2007).

2. J. Heinrich, Int. J. Hyg. Environ. Health, 214, 1-25 (2011).

3. M. R. Ashmore and C. Dimitroulopoulou, Atmos. Environ., 43, 128-141 (2009).

4. R. Barro, J. Reguerio, M.. Llompart and C. GarciaJares, J. Chromatogr. A, 1216, 540-566 (2009).

5. E. Uhde and T. Salthanmmer, Atmos. Environ., 41, 3111-3128 (2007).

6. C. Rusznak, S. Jenkins, P. R. Mills, R. J. Sapsford, J.L. Devalia and R. J. Davies, Rev. fr. Allergol., 38(7S), S80-S90 (1998).
7. S. Lim, K. Lee, S. Seo and S. Jang, Atmos. Environ., 45, 1994-2000 (2011).

8. D. H. Lee and J. D. Chung, J. Environ. Health Sci., 37(3), 193-200 (2011).

9. P. Schneider, I. Gebefügi, K. Richter, G. Wölke, J. Schnelle, H. E. Wichmann, J. Heinrich and INGA study group, Sci. Total Environ., 267, 41-51 (2001).

10. U. Schlink, M. Rehwagen, M. Damm, M. Richter, M. Borte and O. Herbarth, Atmos. Environ., 38, 1181-1190 (2004).

11. S. C. Lee, M. Y. Chiu, K.F. Ho, S.C. Zou and X. Wang, Chemosphere, 48, 375-382 (2002).

12. Method TO-17, "Destermination of Volatile Organic Compounds in Ambient Air Using Active sampling onto Sorbent Tubes", U.S. EPA, 1997.

13. ISO 16000-6, 'Determination of volatile organic compounds in indoor and test chamber air by active sampling on Tenax TA sorbent, thermal desorption and gas chromatography using MS/FID', 2004.

14. Korean Standard method for the Examination of Indoor Air Quality, Ministry of Environment, Korea, 2004.

15. Korean Standard method for the Examination of odor, Ministry of Environment, Korea, 2004.

16. D. W. Yeun, S. M. Hong, H. S. Kang and H. J. Kim, Proceedings of the 2nd Korean Society for Indoor Environment Conference, 101-104 (2005).

17. http://www.scottecatalog.com.

18. R. D. Gibbsons and D. E. Coleman, 'Statistical Methods for Detection and Quantification of Evironmental Contamination', 20th Ed., APHA, New York, 2001.

19. S. J. Jeon, B. J. Kim, J. S. Kim and G. S. Heo, Anal. Sci. Technol., 12(4), 332-340 (1999).

20. H. J. Park, S. k. Jang, S. Y. Seo and J. H. Lim, J. Kor. Soc. Atmos. Environ., 25(1), 38-45 (2009).

21. M. G. Kim, Y. R. Jung, Y. M. Seo, S. H. Nam and Y. J. Kwon, Anal. Sci. Technol., 14(3), 274-285 (2001).

22. S. Y. Park and K. H. Kim, Kor. J. Odor Res. Engin., 5(2), 99-107 (2006).

23. J. W. Ahn, Y. H. Kim, K. H. Kim and H. N. Song, Anal. Sci. Technol., 25(2) 91-101 (2012).

24. S. Y. Park and K. H. Kim, Anal. Sci. Technol., 19(6), 553-558 (2006).

25. S. J. Lee, S. K. Jang, Y. S. Cho, K. M. Jung and G H. Jeong, J. Kor. Soc. Atmos. Environ., 21(2), 191-204 (2005). 